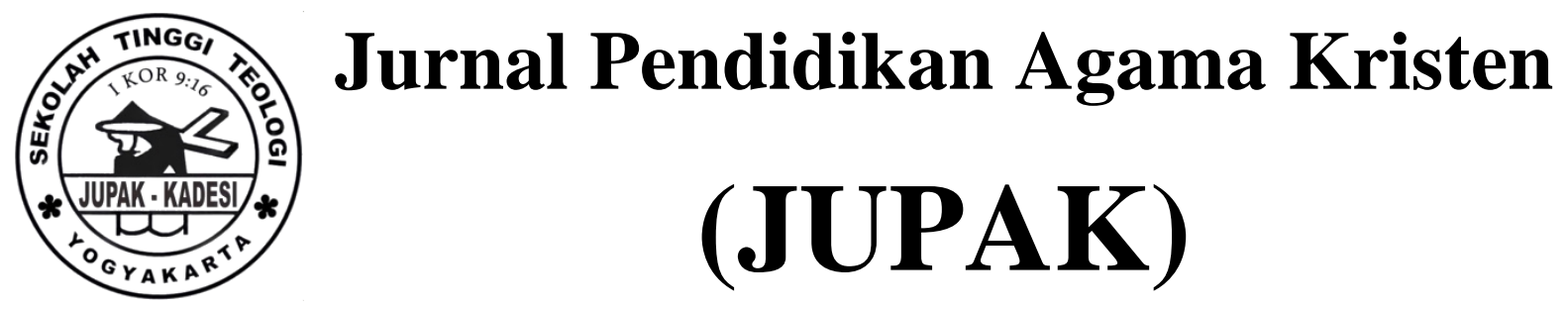

Vol. 1 No. 2 (June 2021) hlm. 92-107

Jurnal Pendidikan Agama Kristen (JUPAK)

e-ISSN 2774-3861

https://ejurnal.sttkadesiyogyakarta.ac.id/index.php/jupak

p-ISSN 2774-6399

\title{
https://doi.org/10.52489/jupak.v2i1.15
}

\section{Fungsi Keluarga Dalam Persepektif Alkitab Sebagai Basis Pendidikan Agama Kristen}

\section{Andreas Sese Sunarko}

Sekolah Tinggi Teologi El-Shadday, Surakarta, andreassesesunarko@gmail.com

\section{Recommended Citation}

Turabian $8^{\text {th }}$ edition (full note)

Andreas Sese Sunarko, "Fungsi Keluarga Dalam Persepektif Alkitab Sebagai Basis Pendidikan Agama Kristen," Jurnal Pendidikan Agama Kristen (JUPAK) 1, no. 2 (June 16, 2021): 1, accessed August 4, 2021, https://ejurnal.sttkadesiyogyakarta.ac.id/index.php/jupak/article/view/15.

American Psychological Association $7^{\text {th }}$ edition

(Sunarko, 2021, p. 1)

Received: 4 April 2021

Accepted: 18 Mey 2021

Published: 16 June 2021

This Article is brought to you for free and open access by Sekolah Tinggi Teologi Kadesi Yogyakarta. It has been accepted for inclusion in Christian Perspectives in Education by an authorized editor of Jurnal Pendidikan Agama Kristen (JUPAK).

For more information, please contact juniorichson1995@gmail.com 


\begin{abstract}
The family is an institution of God Himself (Genesis 2:18-25) aside from the church (Matthew 16:18) obtaining a glorious mandate through God's family to want the birth of Divine offspring (Malachi 2:15), which is a God-fearing and living in its prescribed streets. To achieve the above goal, a Christian Religious Education of faith became something very important. But unfortunately there are Christian families who are unaware of this and are shifting this glorious mandate to the church through sunday school teachers or transferring it to school (through Christian religious teachers). The writer assesses this distraction on the one hand as a parent's misunderstanding of the mandate or on the other hand because of the parents' inability to handle it. The method the writer uses is a descriptive qualitative with a library approach. The writer tapped relevant resources from the bible, books and journals. Starting with a general understanding and juridis about the family, the Biblical basis of the family and its calling, the family's responsibility for Christian Religious Education and the danger of displacing the function of Christisn Religious Education on the third hand and the writer will eventually conclude that it is important to restore the family's function as a base of Christian Religious Education as well as to accord with scriptural values to be so effective in reaching the goal of bearing Divine offspring.
\end{abstract}

Keywords: family, parent, base, Christian religious education, Divine offsprin.

\begin{abstract}
Abstrak
Keluarga sebagai sebuah institusi yang Allah dirikan sendiri (Kej 2:18-25) selain gereja (Mat 16:18) mendapatkan mandat yang mulia yaitu melalui keluarga Allah menghendaki lahirnya keturunan-keturunan Ilahi (Maleakhi 2:15), yaitu keturunan yang takut akan Tuhan dan hidup dalam jalan-jalan yang telah ditunjukkanNya. Untuk mencapai tujuan di atas maka Pendidikan Agama Kristen menjadi sesuatu yang sangat penting. Namun sayang sekali ada keluarga-keluarga Kristen yang kurang menyadari hal ini dan mengalihkan mandat yang mulia ini pada gereja melalui guru-guru sekolah minggu atau mengalihkannya pada sekolah (melalui guru-guru Agama Kristen). Penulis menilai pengalihan ini di satu sisi menunjukkan ketidakpahaman orang tua akan mandat ini atau disisi lain karena faktor ketidakmampuan orang tua menghandle hal ini. Metode yang penulis gunakan adalah kualitatif deskriptif dengan pendekatan pustaka. Penulis memanfaatkan sumber-sumber dari Alkitab, buku-buku, jurnal yang relevan. Dimulai dengan memberikan pemahaman umum dan juridis tentang keluarga, dasar alkitab tentang keluarga dan panggilannya, tanggung jawab keluarga atas Pendidikan Agama Kristen serta bahaya pengalihan fungsi Pendidikan Agama Kristen pada pihak ketiga dan pada akhirnya penulis akan menyimpulkan bahwa mengembalikan fungsi keluarga sebagai basis Pendidikan Agama Kristen merupakan hal yang penting karena selain sesuai dengan nila-nilai alkitab juga sangat efektif dalam mencapai tujuan melahirkan keturunan-keturunan ilahi.
\end{abstract}

Kata Kunci : keluarga, orang tua, basis, Pendidikan Agama Kristen, keturunan Ilahi. 


\section{PENDAHULUAN}

Dalam dunia ini hanya ada 2 (dua) lembaga yang secara khusus benar-benar di bentuk atas inisasi Allah sendiri yaitu lembaga keluarga (Kej 2:18-25) dan lembaga gereja (Mat 16:18). Pada bagian ini penulis akan memfokuskan pada lembaga keluarga sesuai dengan topik dari artikel ini. Lembaga keluarga dibangun oleh Allah dalam rangkaian peristiwa penciptaan secara utuh. Setelah 5 (lima) hari Allah menciptakan alam semesta beserta dengan seluruh isinya maka pada hari 6 (keenam) Allah menciptakan manusia pertama yaitu Adam. Penciptaan manusia Adam merupakan proses yang berbeda dengan penciptaan dibandingkan dengan proses yang dilakukan atas semua ciptaan Allah lainnya, ciptaan yang lain hanya dilakukan Allah dengan mengucapkan perkataan (Firman) saja, namun penciptaan manusia membutuhkan musyawarah Ilahi sebagaimana tercatat dalam Kejadian 1:26 Berfirmanlah Allah: "Baiklah Kita menjadikan manusia menurut gambar dan rupa Kita, supaya mereka berkuasa atas ikan-ikan di laut dan burung-burung di udara dan atas ternak dan atas seluruh bumi dan atas segala binatang melata yang merayap di bumi." Namun demikian meskipun manusia Adam diciptakan Allah sebagai ciptaan yang mulai karena diciptakan serupa dan segambar dengan Allah sebagaimana dicatat dalam Kejadian 1:27 Maka Allah menciptakan manusia itu menurut gambar-Nya, menurut gambar Allah diciptakan-Nya dia; laki-laki dan perempuan diciptakan-Nya mereka, namun Allah melihat bahwa Adam ada dalam kesendirian walaupun ada binatang dan ternak serta tanaman dan tumbuhan di sekitarnya, tetapi hal itu tidaklah sepadan dengan jati diri Adam, dan Allah melihatnya sebagai sesuatu yang tidak baik, sehingga TUHAN Allah berfirman: "Tidak baik, kalau manusia itu seorang diri saja. Aku akan menjadikan penolong baginya, yang sepadan dengan dia." (Kej 2:18) Maka Allah membuat Adam tertidur dan Allah mengambil salah satu tulang rusuknya dan membangun seorang wanita yang akan menjadi penolong bagi Adam yang diberi nama Hawa (Kej 2:19-25) Kehadiran Adam dan Hawa di taman Eden itulah menjadi cikal bakal terbentuknya lembaga keluarga yang pertama yang diinisiasi oleh Allah sendiri.

Selanjutnya Allah memberikan visi besar pada Adam dan Hawa serta semua keturunannya untuk hidup takut akan Alllah dan hidup pada jalan yang ditunjukkannya agar lahir keturunan-keturunan Ilahi (Mal 2:15). Untuk mencapai tujuan ini maka Pendidikan Agama Kristen menjadi sangat penting dan sebagai ujung tombak Pendidikan Agama Kristen adalah keluarga. Sebagaimana dikatakan oleh Tafonao bahwa Pendidikan Agama Kristen sangatlah penting dikerjakan oleh keluarga pada masa kini. Oleh karena keluargalah yang menjadi lembaga yang pertama dan utama pembentukan iman Kristen bagi anak-anaknya 
(Talizaro Tafonao, 2018). Sejalan dengan hal itu Metboki mengatakan bahwa orang tua memiliki peran dalam pembentukan karakter dan kerohanian anak. Oleh karenanya sebagai orang tua yakni sebagai orang yang dipercaya oleh Allah atas anak-anak, itu memiliki tanggung jawab yang sangat besar dalam pendidikan iman Kristen sebagai proses pembentukan karakter dan kerohanian anak-anak agar sesuai dengan Firman Allah (Metboki, 2020). Terlebih pendidikan perilaku atau tindakan yang sesuai dengan ketentuan dan kebenaran Allah yang membawa kepada kesaksian sebagai terang (Waruwu et al., 2020).

Dengan memperhatikan kedua pendapat di atas seharusnya para orang tua menyadari bahwa mandat yang Allah berikan itu adalah sesuatu yang sangat mulia, sehingga sikap yang seharusnya muncul adalah menjadikan mandat itu sebagai sebuah kehormatan dan bukan sebagai sebuah beban. Namun penulis menyadari bahwa ada orang tua yang belum memiliki pemahamaan seperti ini di satu sisi atau disisi yang lain ada juga orang tua karena berbagai kesibukan tidak bisa mengahandle hal ini. Langkah mudah dan pintas yang sering dilakukan orang tua adalah mengalihkan mandat ini pada gereja melalui para pendeta atau guru sekolah minggu ataupun pada guru-guru agama Kristen di sekolah-sekolah umum. Langkah ini menurut penulis tidak selamanya salah namun tidak tepat menurut Firman Allah.

Melalui artikel ini penulis ingin mengajak para orang tua untuk mengembalikan fungsi keluarga sebagai basis Pendidikan Agama Kristen karena hal ini merupakan sesuatu yang sangat penting selain sesuai dengan nila-nilai alkitab juga sangat efektif dalam mencapai tujuan melahirkan keturunan-keturunan ilahi.

\section{METODE}

Metode penelitian yang dipakai dalam penulisan ini adalah kualitatif deskriptif (Zaluchu, 2020), dengan pendekatan studi pustaka. Penulis memanfaatkan sumber-sumber dari Alkitab, buku-buku,jurnal yang relevan. Dimulai dengan memberikan pemahaman tentang keluarga dari sisi yuridis, mencari dasar alkitab tentang keluarga dan panggilannya, tanggung jawab keluarga atas Pendidikan Agama Kristen serta bahaya pengalihan fungsi Pendidikan Agama oleh keluarga pada pihak ketiga dan pada akhirnya penulis akan menyimpulkan bahwa mengembalikan fungsi keluarga sebagai basis Pendidikan Agama Kristen sebagai suatu keharusan dan hal ini merupakan hal yang penting, karena selain sesuai dengan nila-nilai alkitab juga sangat efektif dalam mencapai tujuan melahirkan keturunan-keturunan ilahi. 


\section{PEMBAHASAN}

\section{Hakikat Keluarga}

Hal pertama yang ingin penulis bahas dalam artikel ini adalah keluarga, karena dengan memahami tentang keluarga secara utuh maka pembaca akan dapat menemukan pemahaman yang benar tentang artikel yang penulis buat sehingga mampu memberikan dorongan bagi para orang tua segera menyadari akan tugas mulia yang diberikan Allah kepadanya. Membicarakan keluarga tidak bisa dilepaskan dengan perkawinan. Karena keluarga muncul sebagai akibat dari perkawinan sepasang laki-laki dan perempuan. Menurut UU No. 1 tahun 1974 pasal 1 yang dimaksud dengan perkawinan adalah ikatan lahir batin antara seorang pria sebagai suami istri dengan tujuan membentuk keluarga atau rumah tangga yang bahagia dan kekal berdasarkan Ketuhanan Yang Maha Esa. Penulis melihat ada pesan-pesan penting dari UU ini yaitu bahwa pernikahan hanya boleh dilakukan antara seorang laki-laki dan seorang perempuan, di sini UU ini ingin menegaskan bahwa azas pernikahan yang dianut adalah azaz monogami dan azas heteroseksual. Hal ini menurut sesuai dengan Firman Allah yang tertulis dalam Kejadian 1:24-25 bd Matius Matius 19:5-6. Jadi azas yang dianut dalam UU ini sudah sangat jelas dan mengayomi prinsip yang ada dalam pernikahan Kristen sehingga sampai hari ini dalam praktek pelaksanaan pernikahan Kristen tidak mengijinkan dan menolak permohonan pernikahan sesama jenis dan menolak pernikahan poligami (hal ini ditegaskan juga dalam pasal 3 ay 1 UU Perkawinan ini).

Selain kedua azas dalam UU ini juga mewajibkan pernikahan dilakukan berdasarkan atas Ke Tuhanan yang Maha Esa, artinya dalam proses pernikahan ini negara mewajibkan agar kedua mempelai melibatkan kehadiran dan campur tangan Tuhan (tentunya disesuaikan dengan ajaran agama yang dianutnya) dan hal ini dijelaskan dalam pasal 2 dimana perkawinan akan sah apabila telah dilakukan menurut hukum masing-masing agama dan kepercayaannya. Penulis mencermati pasal 2 UU ini agar pernikahan itu dilakukan sesuai ajaran agama dan kepercayaannya itu mengandung arti agar kedua mempelai itu menikah dengan pasangan yang sesuai dengan ajaran agamanya atau jangan melakukan perkawinan dengan yang berbeda agama (kawin campur), hal inipun sesuai dengan prinsip dalam iman Kristen sebagaimana yang diajarkan dalam Alkitab. Dari pemahaman pasal 2, mengandung konsekuensi bahwa pasangan suami istri ini harus bisa menjaga kehidupan pernikahannya sesuai dengan nilai-nilai agama dan kepercayaan dianutnya termasuk mengajarkan anakanaknya tentang Pendidikan Agama sesuai yang dianut oleh orang tuanya. 
Selain UU Perkawinan maka ada UU lain yang memberikan pemahaman tentang keluarga yaitu UU No.35 Tahun 2014 sebagai Perubahan atas UU No.23 Tahun 2002 tentang Perlindungan Anak yang menyebutkan tentang arti keluarga yaitu : Keluarga adalah unit terkecil dalam masyarakat yang terdiri atas suami istri, atau suami istri dan anaknya, atau ayah dan anaknya, atau ibu dan anaknya, atau keluarga sedarah dalam garis lurus ke atas atau ke bawah sampai dengan derajat ketiga (Pasal 1:3). Selain pemahaman tentang keluarga maka dalam UU ini juga menunjukkan tentang hak anak untuk mendapatkan bimbingan agama dari orang tuanya Pasal 6 Setiap Anak berhak untuk beribadah menurut agamanya, berpikir, dan berekspresi sesuai dengan tingkat kecerdasan dan usianya dalam bimbingan Orang Tua atau wali. Disinilah peran orang tua dalam mendidik anak sesuai dengan ajaran agama Kristen menjadi sangat penting.

Dalam Kamus Besar Bahasa Indonesia (KBBI) yang dimaksud dengan keluarga adalah kelompok terkecil dalam masyarakat. Setiap anggota dalam keluarga mempunyai ikatan batin yang sangat kuat, bahkan sering disebut sebagai kekerabatan yang sangat fundamental dalam masyarakat. Hardi Budiyana berpendapat bahwa keluarga merupakan unit dasar dari seluruh lapisan masyarakat dan keluarga adalah fondasi atau batu penjuru, dimana di atasnya segala sesatu dibangun.(Budiyana, 2018) Pemahaman keluarga juga dapat ditemukan dalam Alkitab baik perjanjian Lama dan Perjanjian Baru. Di bahasa Ibrani ada beberapa istilah yang dapat diartikan ke dalam bahasa Indonesia terhadap kata "keluarga" antara lain: Pertama, dari kisah Akhan (Yos 7:16-18) dimana Akhan berasal dari "suku" (syebet) Yehuda, "kaum" (misypakha) Zerah dan dari "keluarga" (bayit) Zabdi. Jadi, dalam konteks ini ada 3 (tiga) istilah yang saling berhubungan dalam pemahamnnya dengan keluarga yaitu: suku (syebet), kaum (misypakha), keluarga (bayit); kalau diperhatikan dengan cermat maka Akhan masih disebutkan sebagai keluarga (bayit) dari kakeknya Zabdi. Sehingga istilah Ibrani untuk keluarga yang sering diartikan ke dalam bahasa Indonesia adalah kata bayit. Kata ini juga dapat diterjemahkan baik dalam arti rumah ataupun bangunannya maupun gedungnya. Dapat juga diterjemahkan dalam pemahaman yang meliputi semua orang yang menghuni rumah atau bangunan, misalnya Abraham dan orang-orang yang terlahir di rumahnya disebut sebagai keluarga dan istilah yang digunakan adalah bayit (Kej 14:14).

Dalam Perjanjian Baru pada umumnya juga menggunakan beberapa istilah yang lazimnya diartikan ke dalam bahasa Indonesia sebagai kata "keluarga", diantaranya :Pertama, yaitu kata "oikos", kata ini sering diartikan ke dalam bahasa Indonesia sebagai kata "keluarga", "rumah" atau "rumah tangga". Kata "oikos" berasal dari bahasa Yunani yang 
maknanya hampir sama dengan "bayit" dalam bahasa Ibrani. Kata ini juga sering diterjemahkan dengan kata "keluarga" atau "keturunan" (I Tim 5:4,8 ; Tit 1:11 bd. Luk 1:27,69). Kedua, yaitu kata "patria". Kata ini mempunyai makna yang sama dengan "misypakha" dalam bahasa Ibrani. Sebagai contoh Yusuf disebut sebagai keturunan (patria) Daud. Kata ini dapat juga diterjemahkan dengan kata leluhur dalam arti satu suku atau semua bangsa di bumi (Kis 3:25). Bisa juga diartikan dalam pengertian seluruh umat manusia (Ef 3:14) yang konotasinya bahwa semua keturunan (patria) berasal dari Allah yang disebut dengan Bapa. Istilah lain dalam Perjanjian Baru yang dapat diartikan "keluarga" adalah "genos". Kata ini lebih menunjuk pada satu "keluarga" atau "suku" dan "bangsa". (Pasaribu, 2020, p. 5).

Dari semua pendapat di atas penulis dapat menyimpulkan bahwa yang dimaksud dengan keluarga adalah lembaga terkecil dalam masyarakat yang terbentuk melalui proses perkawinan yang sah menurut agama dan disahkan dan dicatatkan pada lembaga negara yang berwenang, keluarga ini dalam perkembangannya terdiri dari ayah,ibu dan anak-anak sebagai keluarga inti atau "a nuclear family". Sejalan dengan pendapat Hardi Budiyana yang mendefinisikan keluarga sebagai unit dasar dari seluruh lapisan masyarakat dan keluarga adalah fondasi atau batu penjuru dimana di atasnya segala sesatu dibangun. Sehingga memiliki prinsip bahwa Keluarga Kristen adalah keluarga yang dibentuk oleh Tuhan dan memiliki tujuan untuk menyatakan kemuliaan Tuhan (Angin et al., 2020).

\section{Pendidikan Agama Kristen}

Pendidikan Agama Kristen merupakan pendidikan yang sangat penting karena memberikan pondasi iman Kristen kepada setiap orang yang dapat diperoleh melalui lembaga keluarga, sekolah dan gereja. Dalam konteks ini penulis akan memfokuskan Pendidikan Agama Kristen yang dilakukan oleh para orang tua dalam keluarga-keluarga Kristen. Sebelum membahas lebih lanjut tentang Pendidikan Agama Kristen yang dilakukan oleh para orang tua di keluarga Kristen maka hal yang perlu diketahui adalah tentang Pendidikan Agama Kristen itu sendiri. Menurut Warner C.Gradedorf mendefinisikan Pendidikan Agama Kristen adalah: proses pengajaran dan pembelajaran yang berdasarkan Alkitab, berpusat pada Kristus dan bergantung pada Roh Kudus yang membimbing setiap pribadi pada semua tingkat pertumbuhan melalui pengajaran masa kini kearah pengenalan dan pengalaman rencana dan kehendak Allah melalui Kristus dalam setiap aspek kehidupan, dan melengkapi mereka bagi pelayanan yang efektif yang berpusat pada Kristus sang Guru Agung dan perintah yang mendewasakan para murid (Kristanto, 2006, pp. 4-5). Roh Kudus juga 
berperan menuntun kepada seluruh kebenaran Allah, sehingga orang yang dituntunnya terhindar dari siasat penyesatan, dan dapat mengenal Allah dengan benar (Arifianto \& sumiwi Rachmani, 2020).

Selain itu ada pendapat lain yang mengungkapkan bahwa pendidikan Agama Kristen adalah usaha sadar dari gereja dalam mendidik jemaatnya dalam kaitannya dengan pewarisan iman Kristen dalam kerangka kebenarannya, sebagaimana yang diamanatkan dalam kitab suci dan melatih mereka untuk hidup harmonis sejalan dengan iman, sehingga mereka dapat menjadi anggota jemaat yang dewasa yang menyadari dan meyakini iman dan mewujudkan dalam kehidupan sehari-hari. Begitu juga dengan Robert Boelhke memberikan rumusan sebagai berikut Pandidikan Agama Kristen adalah usaha gereja dengan sengaja menolong orang dari segala umur yang dipercayakan kepadapemeliharaan-Nya untuk menjawab penyertaan Tuhan dalam kristus Yesus, Alkitab dankehidupan gereja supaya mereka di bawah pimpinan Roh Kudus yang dapat diperlengkapi untuk melayani di tengah lembaga gereja, masyarakat dan dunia (alam).

Werner C. Graendorf memberikan rumusan yang lain yaitu: Pendidikan Agama Kristen adalah proses pengajaran dan pembelajaran yang bersumber pada Alkitab, berpusat pada Tuhan Yesus Kristus dan bergantung penuh pada kuasa Roh Kudus, yang membimbing setiap orang dalam segala tingkatan pertumbuhan iman. Melalui pengajaran konteks masa kini diarahkan pada pengenalan dan pengalaman rencana kehendak Allah melalui pribadi Tuhan Yesus Kristus pada setiap aspek kehidupan untuk memperlengkapi pelayanan yang efektif yang berpusat pada Tuhan Yesus Kristus sang Guru Agung yang mendewasakan murid-muridNya (Budyana, 2011, pp. 6-8). Dari semua pendapat di atas penulis dapat menyimpulkan bahwa Pendidikan Agama Kristen merupakan usaha dari gereja yang dilakukan secara sadar dan sengaja untuk membantu dan menolong jemaatnya bertumbuh dalam pengalaman dan pengenalan akan Tuhan melalui proses pembelajaran yang bersumber pada Alkitab dan berpusat pada Tuhan Yesus Kristus dan bergantung penuh pada Roh Kudus, agar semua jemaat yang dipercayakan oleh Tuhan Yesus Kristus itu mengalami pertumbuhan iman dan pengenalan akan Tuhan Yesus Kristus, yang mana pada akhirnya semuanya itu dapat diwujudkan dalam kehidupan sehari -hari.

\section{Pendidikan Agama dalam Perjanjian Lama}

Nenek moyang kaum Israel, Abraham, Ishak dan Yakub menjadi mentor bagi kaum keluarganya. Dalam kapasitasnya sebagai orang tua mereka bukan saja bertindak sebagai 
imam yang menjadi penghubung antara Allah dengan dirinya, tetapi mereka juga berfungsi sebagai guru yang mengajarkan tentang fakta-fakta Allah yang ajaib dengan janji-janjiNya membawa berkat bagi Israel secara turun temurun. Tuhan telah memanggil Abrahan untuk melayani kehendakNya yang mulia itu demi keselamatan semua bangsa di bumi ini, dan Abraham menyampaikan maksud Allah itu melalui bimbingan pada semua anak cucunya. Kemudian Ishak meneruskan tugas ini yang terus berlanjut pada Yakub yang mengajarkan segala pengajaran yang penting ini kepada anak-anaknya. Yusuf sebagai generasi selanjutnya juga mengajarkan nilai-nilai iman kepada anak-anaknya dimana saja termasuk pada saat ada di pengasingan.

Setelah generasi Yusuf maka munculah Musa sebagai pemimpin bangsa Isarel yang legendaris, Musa selain diangkat oleh Allah sebagai pemimpin bangsa Israel tetapi juga sekaligus menjadi guru dan pemberi hukum-hukum bagi umat Israel yang besar jumlahnya itu. Musa mendidik mereka di padang belantara dan mengatur pendidikan itu sedemikian rupa agar tepat dalam meletakan dasar-dasar iman bagi seluruh kehidupan umat Tuhan sehingga nantinya dapat dilanjutkan oleh para penerusnya. Pada saat jaman Musa berakhir dilanjutkan pada masa hakim-hakim dimana muncul seorang guru atau pengajar yang baik yaitu Samuel dimana Samuel selain mengajarkan tentang Firman Tuhan juga mengajarkan tentang hukum-hukum Tuhan, selanjutnya giliran para nabi yang juga menjadi pengajar sekaligus menjadi pembawa berita tentang kehadiran Mesias di kelak kemudian hari. Dari pemaparan di atas penulis memperhatikan proses pengajaran agama dalam Perjanjian Lama dilakukan oleh para orang tua kepada anak cucubya, sehingga orang Israel dapat menyampaikan hal yang sama pada setiap generasinya (Enklaar \& Homrighausen, 2011, p. 2).

\section{Pendidikan Agama dalam Perjanjian Baru}

Apabila hendak menyelidiki soal Pendidikan agama dalam hubungannya dengan Perjanjian Baru, maka pertama-tama dan khususnya kita harus mengarahkan pandangan kita pada Tuhan Yesus sendiri karena selain jabatannya sebagai penebus dan pembebas maka Tuhan Yesus juga menjadi seorang guru yang Agung. KeahlianNya sebagai seorang guru umumnya diperhatikan dan dipuji oleh rakyat Yahudi; mereka dengan sendirinya menyebut Dia "Rabbi". Ini tentu suatu gelar kehormatan, yang menyatakan betapa Ia disegani dan dikagumi oleh orang sebangsaNya selaku seorang pengajar yang mahir dalam segala soal ilmu ketuhanan. Sebab Ia mengajar mereka "sebagai orang yang berkuasa, tidak seperti ahli- 
ahli taurat yang biasa mengajar mereka" (Mat 7:29). Sebab Pendidikan Kristen memiliki landasan teologis yang kuat dalam Perjanjian Baru. Landasan teologis dalam Perjanjian Baru nyata dalam teladan Tuhan Yesus Kristus Sang Guru Agung di mana selain Tuhan Yesus mengajar di berbagai kesempatan dengan berbagai metode yang kontekstual, Ia juga menjadikan pendidikan sebagai bagian dalam amanat agung-Nya (Purwoto et al., 2020).

Kehebatan pengajaran Tuhan Yesus selain berasal dari hikmat Allah tentunya kalau ditelusuri dari masa Pendidikan Yahudi masa Tuhan Yesus telah berjalan dengan ketat. Anak-anak Yahudi sejak dini sudah mulai diajari hukum agama sehingga hukum agamanya tertanam dan tidak mungkin dilupakan. Anak-anak Yahudi umur 0-4 tahun Pendidikan di bawah asuhan ibunya sedangkan umur 5 tahun dibawah asuhan ayahnya. Pada umur 6 tahun mereka pergi ke sekolah untuk pertama kali. Setelah dapat membaca mereka diberi gulungangulungan perkamen kecil bagian dari Taurat. Bagian-bagaian itu meliputi Shema Yisrael, (U1 6:4-9, 11:13-21,Bil 15:37-41), Hallel (Mzm 113-118), Kisah Penciptaan (Kej 1-5), Hukum Upacara (Im 1-8) (Barclay, 2001, pp. 8-9).

Yesus hidup dalam budaya Yahudi yang memiliki sistem Pendidikan dan Lembaga pendidikannya sudah maju melalui sinagoge-sinagoge dan Beth-Sepher, BetTalmud, Beth-haMidras. Sinangoge bukan hanya berfungsi sebagai tempat beribadah, tetapi juga tempat orang-orang Yahudi menerima pengajaran tentang Taurat. Bahkan Philo menamakan sinagoge itu didaskaleia, yaitu suatu tempat dimana pengajaran disampaikan (R.Boehlke, 1991, p. 41). Dengan melihat ketatnya pendidikan agama yang ada di masyarakat Yahudi serta dengan dukungan himat Allah yang ada dalam diri Tuhan Yesus maka tidak terlalu berlebihan apabila Dia layak menerima sebutan Rabbi. Hubungan di anatara Yesus sebagai Rabbi dan para pengikutnya sebagai murid-muridNya menunjukkan hubungan guru-murid yang begitu dekat dapat dilihat peristiwa murid-murid pergi membeli makanan untuk guru mereka (Yoh 4:8,27,31-34). Dalam bukunya The Dictionary of Biblical Imagery menjelaskan bahwa Yesus sebagai Rabbi karena ajaran Yesus disesuaikan dengan kebutuhan dan pertanyaan pendengarNya dan Ia secara efektif menjawab situasi kehidupan yang diperhadapkan kepadaNya (Ryken et al., 1998, p. 25).

Yang kedua dapat dilihat dari sososk Paulus adalah seorang guru yang ulung. Ia benar-benar tokoh penting di lapangan Pendidikan agama. Paulus sendiri dididik untuk menjadi rabbi bagi bangsanya. Ia mahir dalam pengetahuan akan Taurat dan ia dilatih mengajar orang lain tentang agama kaum Yahudi. Paulus berkeyakinan yang kuat dan teguh imannya. Ia selalu siap sedia untuk bertukar pikiran, mengajar, menegur dan mengajak. Pasti 
ia seorang ahli pidato yang besar bakatnya. Paulus mengajar di rumah-rumah tempat ia menumpang, di Gedung-gedung yang disewanya, di Lorong-lorong kota atau dipadangpadang, di atas kapal dan dalam bengkelnya, dipasar-pasar dan dalam kumpulan kaum filsuf. Tak ada tempat yang dianggapnya kurang layak untuk menyampaikan berita tentang Juru selamatnya.

Rasul Paulus juga mengajar melalui surat-suratnya. Segala soal dan kesulitan yang muncul dalam jemaat-jemaat yang didirikannya ataupun yang timbul di antara kaum Kristen yang belum dikunjunginya, semuanya itu dipakaianya untuk menguraikan pokok-pokok kepercayaan atau kesusilaan Kristen yang bersangkutan dengan hal-hal itu. Kebiasaan itu sungguh-sungguh menguntungkan seluruh umat Kristen di kemudian hari (Enklaar \& Homrighausen, 2011).

Dan yang ketiga nampak dalam komunitas jemaat mula-mula Sejak mulai berdirinya maka jemaat Kristen menjunjung pengajaran agama. Akibatnya mereka mulai berdoa, berbicara mengenai pengajaran dan perbuatan-perbuatan Tuhan Yesus Kristus, makan sehidangan dan merayakan perjamuan kudus. Mereka yakin bahwa sejak Roh Kudus turun ke atas mereka maka mereka menjadi Israel baru. Mereka mulai berkotbah dan mengajar dan banyak orang lain yang menjadi percaya pada Tuhan Yesus. Sedari jaman Perjanjian baru jemaat Kristen mula-mula mementingkan Pendidikan agama. Tugas mengajar itu diserahkan khususnya kepada kaum guru yang telah mempunyai karunia dan latihan istimewa untuk pekerjaan yang mulia itu, tetapi seluruh jemaat tetap mendukung dan mendoakan mereka itu. Mulai dari abad pertama Masehi, Pendidikan Agama Kristen menyiapkan orang untuk masuk kedalam persekutuan jemaat Kristus dan setelah disambut dalam jemaat itu mereka dididik terus supaya semakin lama semakin berakar dalam pengetahuan dan pengenalan yang mendalam pada Tuhan Yesus Kristus, Kepala Gereja itu (Enklaar \& Homrighausen, 2011).

\section{Tanggung Jawab Keluarga dalam Pendidikan Iman (Agama Kristen)}

Menurut pendapat Ruwi Hastuti Pendidikan Agama Kristen bukanlah produk gereja atau kurikulum sekolah semata namun hasil dari para tokoh Alkitab yang menekankan pendidikan dalam dimensi keluarga. Artinya Pendidkan Agama mengacu pada dasar yang jelas dalam Alkitab baik Perjanjian Lama maupun perjanjian Baru (Hastuti, 2013). Pada dasarnya Pendidikan Agama Kristen bukanlah sekedar pelajaran atau kurikulum yang dilaksanakan di sekolah umum atau di lembaga gereja, melainkan Pendidikan Agama Kristen berawal dalam keluarga itu sendiri. Pendidikan Agama Kristen dibangun dalam keluarga 
yang dapat disinergikan bersama sekolah dan gereja (Narramore, 1996, p. 6). Pertanyaan yang mungkin muncul dibenak setiap orang mengapa mesti keluarga yang melakukannya dan bukan sekolah atau gereja yang lebih kompeten dalam melakukan Pendidikan Agama Kristen? Jawababnya adalah karena keluarga merupakan sekolah pertama atau sekolah pembelajaran kehidupan, yang oleh Gatot Setyo menyatakan: Sekolah adalah laboratorium kecil tempat belajar anak-anak. Sepertiga usia mereka dihabiskan dengan belajar di sekolah, sedangkan selebihnya dua pertiga waktunya ada dalam aktifitas di keluarga. Jadi keluarga adalah tempat belajar utama bagi anak-anak (Poespowardojo, 2018, p. 49). Dan juga Keluarga memiliki peran penting dalam mendidik anggotanya untuk bersama bertumbuh dalam kerohanian (Arifianto, 2020).

Alkitab sendiri juga menunjukkan bahwa Pendidikan Agama Kristen harus dilakukan oleh para orang tua bukan pada guru-guru sekolah minggu di gereja ataupun guru-guru agama kristen di sekolah, beberapa prinsip tentang hal ini ditunjukkan di bawah ini: Pertama, pendidikan adalah tugas orang tua, mereka harus memperhatikan pendidikan di dalam keluarga. Alkitab sebagai dasar dalam mendidik dan membimbing manusia pada kebenaran, agar berperilaku sesuai dengan norma-norma ajaran kristen (Waruwu et al., 2020, p. 43). Pimpinan Tuhan akan menyertai segala upaya mendidik anak dalam keluarga, sedangkan sekolah hanyalah mitra orang tua dalam mendidik anak termasuk dalam hal Pendidikan Agama Kristen (U1 6:4-8) (Tung, 2017, p. 26). Kedua, keluarga menjadi tempat yang mutlak dalam dimata Allah, dalam seluruh catatan Alkitab dibuktikan bahwa keluargalah yang dipakai Allah sebagai saluran berkat dan jalan keselamatan yang dirancangkan olrh Allah bagi umat manusia, maka keluargalah yang memegang peranan terpenting dalam penyelengaraan Pendidikan Agama Kristen bahkan lebih penting pula dari segala jalur lain yang dipakai gereja atau sekolah untuk pendidikann (Enklaar \& Homrighausen, 2011).

Ketiga, contoh nyata adalah keluarga bangsa Israel menjadi tempat yang sangat penting dan strategis yang menjadi sentral pendidikan, nilai-nilai kehidupan, nilai-nilai iman, nilai-nilai agama, nilai-nilai nasionalisme state (kebangsaan), nilai-nilai kedisipilinan, ketertiban dan ketaatan kepada Tuhan, agar semua orang takut akan Tuhan. Meskipun ada perndidikan persekolahan formal di lingkungan Israel, seperti halnya Beth-Hasepher (Rumah Buku untuk tingkat SD), Beth Talmud (RumahTalmud untuk tingkat SMP) dan Beth Hammidrasy dimana mereka belajat Taurat, Misyna Talmud, Haggadah dan lainnya. Namun pendidikan utama yaitu pendidikan agama dilakukan dalam keluarga mereka masing-masing. Keluarga tidak menyerahkan begitu saja pendidikan nilai-nilai utama agama kepada sekolah- 
sekolah formal. Dari sini bisa terlihat bahwa orang tua menjadi pendidik, pengajar utama yang baik dan bertanggung jawab bagi anak-anak mereka (Iswanto, 2020, pp. 135-136). Dari paparan di atas maka tidak dapat disangkal lagi bahwa keluargalah yang menjadi ujung tombak dan penanggung jawab pertama dan utama atas penyelenggaraan Pendidikan Agama Kristen, gereja dan sekolah hanya mitra dalam pencapaian tujuan dari penyelenggaraan Pendidikan Agama Kristen.

\section{Bahaya-Bahaya Pengalihan Pendidikan Agama Kristen Pada Pihak Ketiga}

Setelah mengetahui bahwa keluargalah pemegang mandat pertama dan utama dalam Pendidikan Agama Kristen di keluarga-keluarga Kristen, namun demikian dalam faktanya gereja dan sekolah-sekolah dalam panggilannya juga menjalankan tugas ini, hanya saja perlu dipahami bahwa ada bahaya-bahaya apabila keluarga menyerahkan sepenuhnya Pendidikan Agama Kristen kepada guru-guru sekolah minggu ataupun guru-guru Pendidikan Agama Kristen di sekolah. Beberapa bahaya yang perlu diketahui antara lain: Pertama dari sisi gurugurunya. Apakah guru-guru yang diutus oleh gereja baik dikelas-kelas sekolah minggu maupun di sekolah-sekolah untuk mengajarkan Pendidikan Agama Kristen itu sungguhsungguh cakap menjadi guru? Meskipun itu seorang pendeta sekalipun apakah ia telah mendapatkan pendidikan di sekolah teologi yang mempelajari teori dan praktik Pendidikan Agama Kristen? Karena ada dua syarat mutlak yang harus dipenuhi yaitu mereka adalah seorang Kristen sejati yang telah lahir baru dan mereka terbukti cakap mengajar baik dari sisi teori pendidikan maupun praktik Pendidikan Agama Kristen. Kalau tidak memenuhi hal-hal ini maka akan sangat membahayakan bagi anak-anak yang diajarnya. Kedua, dari sisi rencana pembelajarannya. Bahan-bahan apakah yang perlu diajarkan dan bagaimanakah pembagian atas tahun-tahun pelajaran di sekolah-sekolah umum itu? Pendidikan Agama Kristen jangan hendaknya dirancangkan sewenag-wenang saja. Kalau kurikulum Pendidikan Agama Kristen dibuat asal-asalan maka akan membahayakan bagi pertumbuhan iman bagi anaka-anak didik yang mengikutinya.

Ketiga, cara-cara mengajar. Metode manakah yang harus dipakai dalam Pendidikan Agama Kristen di sekolah-sekolah? Sekarang dapat dimengerti apa sifat khusus pengajaran semacam ini dimana secara umum Pendidikan Agama Kristen dijarkan hanya sebatas pengetahuan yang menyentuh akal manusia saja tanpa memikirkan hubungan dan ekspresi relegiositas iman seseorang pada Allah. Ini yang paling berbahaya. Oleh karena itu orang tua harus memperhatikan hal ini dan harus memahami bahaya-bahaya yang dapat mengancam 
anak-anaknya apabila orang tua tidak mau menjadi pendidik dan pengajar yang utama di keluarganya (Enklaar \& Homrighausen, 2011).

\section{REKOMENDASI PENGEMBANGAN PENELITIAN}

Penulis berharap hasil penelitian ini dapat bermanfaat bagi gereja, lembaga pendidikan dan terlebih kepada keluarga. Kiranya saran atau kritik dapat diberikan kepada penulis oleh semua pembaca agar dikesempatan selanjutnya penulis dapat lebih lagi dalam mengembangkan kemampuan yang telah diberikan oleh Tuhan. Penelitian ini masih dapat dikembangkan dengan melihat relevansi penelitian ini, dengan fakta-fakta di tahun-tahun selanjutnya, oleh orang-orang yang mau menguji atau mengembangkannya. Kemudian, penulis juga berharap kiranya penelitian ini dapat menjadi referensi dari penulis-penulis berikutnya yang sedang menulis tentang topik-topik seputar pembahasan yang ada pada artikel ini.

\section{KESIMPULAN}

Pendidikan Agama Kristen bukanlah produk gereja atau produk sekolah melainkan mandat Allah yang diberikan oleh para orang tua untuk mengerjakannya sejak dini (Ul 6:4-8) sehingga para orang tua diharapkan memahami hal ini dengan memberikan respon yang posistif dengan menerima mandat ini sebagai sebuah kehormatan dan bukan beban. Mengalihkan tanggung jawab Pendidikan Agama Kristen yang diamanatkan oleh para orang tua di keluarga-keluarga Kristen kepada guru-guru sekolah minggu di gereja atau guru-guru Pendidikan Agama Kristen di sekolah-sekolah bukanlah solusi yang tepat, sekedar melakukan sinergi itu sah-sah saja namun hanya untuk waktu sementara bukan sebuah proses yang dibakukan atau dipermanenkan. Selain itu pastinya melanggar mandat Allah tetapi perlu juga memikirkan bahaya-bahaya yang ada atas tindakan pengalihan mandat tersebut sebagaimana sudah dipaparkan sebelumnya.

Langkah paling tepat sekaligus menjadi tujuan akhir dari artikel ini adalah adanya gerakan yang berupa kesadaran dari para orang tua sebagai penerima mandat Allah ini secara sadar dan bertanggung jawab mengambil alih dan mengembalikan fungsi keluarga ini sebagai basis Pendidikan Agana Kristen, mengingat waktu terbanyak anak-anak ada di dalam keluarga oleh karenanya para orang tua punya waktu yang maksimal untuk melakukan proses Pendidikan Agama Kristen secara terstruktur, sistematis, masif dan terukur maka penulis 
yakin kalau hal ini dikerjakan dengan baik akan melahirkan keturunan-keturunan Ilahi sebagaimana yang dimandatkan Allah kepada keluarga-keluarga Kristen.

\section{BIODATA}



Andreas Sese Sunarko, M.Th adalah penulis yang cukup banyak membahas tentang karakter hidup yang diambil dari perspektif Alkitab. Dia telah selesai menempuh pendidikan Sarjana Hukum di UKSW Salatiga dan Master Teologi di Intheos Surakarta. Dia masuk dalam salah satu keluarga besar di STT El-Shadday. Penelitiannya selalu memperlihatkan sosok yang cakap dalam mengintegrasikan pesan Alkitab pada kehidupan Masa Kini dan budaya-budaya di Indonesia.

\section{Andreas Sese Sunarko, M.Th}

Alamat: Perum Amarta A-7 Jl. Walisongo RT.01-RW 08 ,

Kel.Mangunsari, Kec.Sidomukti, Kota Salatiga.

Surel: andreassesesunarko@gmail.com

\section{DAFTAR PUSTAKA}

Angin, Y. H. P., Yeniretnowati, T. A., \& Arifianto, Y. A. (2020). Peran Keluarga Kristen untuk Bertahan dan Bertumbuh dalam Menghadapi Tantangan di Era Disrupsi dan Pandemi Covid-19. JURNAL TEOLOGI RAHMAT, 6(2), 128-141.

Arifianto, Y. A. (2020). Pentingnya Pendidikan Kristen dalam Membangun Kerohanian Keluarga di Masa Pandemi Covid-19. Regula Fidei Jurnal Pendidikan Agama Kristen, 5(2), 94-106.

Arifianto, Y. A., \& sumiwi Rachmani, A. (2020). Peran Roh Kudus dalam Menuntun Orang Percaya kepada Seluruh Kebenaran Berdasarkan Yohanes 16 : 13. Jurnal Diegesis, 3(1), $1-12$.

Barclay, W. (2001). Duta Bagi Kristus. Jakarta: BPK Gunung Mulia.

Budiyana, H. (2018). Perspektif Alkitab Terhadap Keluarga Kristen. Regula Fidei, 3(2), 137145.

Budyana, H. (2011). Dasar-Dasar Pendidikan Agama Kristen. STT Berita Hidup. 
Enklaar, I. H., \& Homrighausen, E. G. (2011). Pendidikan Agama Kristen. Jakarta: BPK Gunung Mulia.

Hastuti, R. (2013). Pendidikan Agama Kristen Dalam Keluarga Sebagai Pusat Bermisi. Jurnal Antusias, 2(4), 23-68.

Iswanto, D. H. (2020). “Membangun Keluarga Yang Tangguh di Tengah Pandemi Covid19.” CV.Istana Agency.

Kristanto, P. L. (2006). Prinsip dan Praktek PAK Penuntun bagi Mahasiswa Teologi dan PAK, Pelayan Gereja, Guru Agama dan keluarga Kristen. Yogyakarta: Andi Offset.

Metboki, R. J. A. (2020). Peranan Orangtua Kristen Dalam Membentuk Karakter Anak. SESAWI: Jurnal Teologi Dan Pendidikan Kristen, 1(2), 55-63.

Narramore, C. H. (1996). “Liku-Liku Problem Rumah Tangga.” Kalam Hidup.

Pasaribu, M. (2020). “Merajut Prinsip-Prinsip Dasar Pernikahan dan Keluarga Bahagia.” Gandum Mas.

Poespowardojo, A. S. P. (2018). “Keluarga Sekolah Pembinaan Karakter Awal : Pendukung Revolusi Mental." Yayasan Pustaka Nusatama.

Purwoto, P., Budiyana, H., \& Arifianto, Y. A. (2020). Landasan Teologis Pendidikan Kristen dalam Perjanjian Baru dan Relevansinya bagi Pendidikan Kristen Masa Kini.

DIDAKTIKOS: Jurnal Pendidikan Agama Kristen, 3(1), 34-48.

R.Boehlke, R. (1991). “Sejarah Perkembangan Pikiran dan Praktek Pendidikan Agama Kristen: Dari Plato sampai IG.Loyola.” BPK Gunung Mulia.

Ryken, L., C.Wilhoit, J., \& Longman, T. (1998). “The Dictionary Biblical Imagery.” Inter Versity Christian Fellowship.

Talizaro Tafonao. (2018). Peran Pendidikan Agama Kristen Dalam Keluarga Terhadap Perilaku Anak. Talizaro Tafonao, 3(2), 121-133.

Tung, K. Y. (2017). “Terpanggil Menjadi Pendidik Kristen Yang Berhati Gembala.” Penerbit Andi.

Waruwu, M., Arifianto, Y. A., \& Suseno, A. (2020). Peran Pendidikan Etika Kristen dalam Media Sosial di Era Disrupsi. Jurnal Pendidikan Agama Kristen (JUPAK), 1(1), 38-46. https://doi.org/10.52489/jupak.v1i1.5

Zaluchu, S. E. (2020). Strategi Penelitian Kualitatif dan Kuantitatif Di Dalam Penelitian Agama. Evangelikal: Jurnal Teologi Injili Dan Pembinaan Warga Jemaat, 4(1), 28-38. https://doi.org/10.46445/ejti.v4i1.167 